\title{
End-Use Properties of Pineapple Leaf Fibre Filled Natural Rubber
}

\author{
Chinenye C. Ekwueme ${ }^{1 *}$, Isaac 0. Igwe ${ }^{2}$, Anokwute 0. Vivian ${ }^{3}$ \\ Department of Polymer and Textile Engineering, Federal University of Technology, Owerri, Nigeria \\ Email: *chinenyecharity10@gmail.com, zik3gh@gmail.com, viviananokwute@gmail.com
}

How to cite this paper: Ekwueme, C.C., Igwe, I.O. and Vivian, A.O. (2019) End-Use Properties of Pineapple Leaf Fibre Filled Natural Rubber. Journal of Minerals and Materials Characterization and Engineering, 7, 435-445.

https://doi.org/10.4236/jmmce.2019.76030

Received: September 9, 2019

Accepted: November 15, 2019

Published: November 18, 2019

Copyright (๑ 2019 by author(s) and Scientific Research Publishing Inc. This work is licensed under the Creative Commons Attribution International License (CC BY 4.0).

http://creativecommons.org/licenses/by/4.0/

\begin{abstract}
The effects of incorporating pineapple leaf fibre (PLF) as a filler on the end-end properties of natural rubber vulcanizates were studied at different filler contents and particle sizes. The pineapple leaf fibre was used within filler contents, 0 to $40 \mathrm{phr}$ at the following filler particle sizes, 75, 150 and 300 $\mu \mathrm{m}$. The PLF was characterized for filler properties while carbon black (N330) served as the reference filler. The natural rubber vulcanizates were compounded on a two-roll mill. Results showed that the abrasion resistance of filled natural rubber vulcanizates was generally higher than that of the unfilled natural rubber vulcanizate at filler content, $5 \mathrm{phr}$, and for PLF (150 and $300 \mu \mathrm{m})$ and carbon black filled natural rubber vulcanizates, the abrasion resistance decreased within filler content, 5 to $20 \mathrm{phr}$ after which it increased with filler content. CB exhibited better abrasion resistance in the vulcanizates than PLF at filler contents greater than $20 \mathrm{phr}$. The hardness of filled natural rubber vulccanizates was generally greater than that of unfilled vulcanizate and increased with increases in filler particle size at filler contents, 10 and 20 phr. The specific gravity of the rubber vulcanizates increased gradually with the increase in filler content at filler content greater than $5 \mathrm{phr}$, and increased with increases in filler particle size at any filler content considered. The swelling index of filled natural rubber vulcanizates in toluene generally decreased with increasing filler particle size at filler contents, 5, 10 and $40 \mathrm{phr}$ whereas the swelling index for PLF $(150 \mu \mathrm{m})$ filled natural rubber decreased with increases in filler content. CB filled vulcanizates absorbed the highest amount of toluene (2.5\%) in the vulcanizates at filler content, 40 phr. PLF (150 and $300 \mu \mathrm{m})$ generally gave optimum performances in the end-use properties of the rubber vulcanizates determined within filler contents, 30 and $40 \mathrm{phr}$. The incorporation of pineapple leaf fibre into natural rubber was found to improve the end-use properties of natural rubber vulcanizates and therefore, has potential in the formulation of natural rubber products.
\end{abstract}




\section{Keywords}

Natural Rubber, Pineapple Leaf Fibre, Carbon Black, Filler, End-Use Properties

\section{Introduction}

Natural rubber which is an elastomer is rarely used in its natural state for engineering applications. The compounding of rubber, therefore, involves the selection and combination of ingredients that possess properties necessary for the rubber product to satisfy its intended use. The ingredients in rubber compounding include rubber (elastomer), cure systems (generally sulphur and zinc oxide), fillers, processing aids, and miscellaneous ingredients which are added to achieve particular properties. Different rubbers, synthetic or natural, have their advantages and disadvantages in the compounding of rubber products. For example, natural rubber is highly resilient and possesses excellent strength characteristics; styrene-butadiene rubber (SBR) performs well in applications that require good abrasion resistance against thermal degradation and generation of cracks, while neoprene rubber is suitable for use in flammable environments [1]. The physical properties considered in the selection of a base polymer (rubber) for rubber compounding include: hardness, abrasion resistance, tensile strength, tear resistance, modulus (stiffness), permanent set, hysteresis, ageing characteristics, fatigue resistance, gas and solvent permeability among others [2].

Carbon black is the most important ingredient that affects the properties of natural rubber vulcanizate apart from natural rubber and the cure system. It assists in the compounding process, reduces the need for curatives and cure time because of its activating effect. Carbon black also serves as reinforcement and imparts abrasion resistance to rubbers [1]. The properties impacted by carbon black to rubber compound depend on several factors such as particle size, structure, physio-chemical nature of the surface area, and particle porosity. However, carbon black is a costly filler because of its origin from petroleum, and causes environment pollution that affects public safely. These drawbacks on the use of carbon black in the rubber industry have led to the search for new inorganic and natural fillers from renewable resource to replace carbon black wholly or in part in compounding natural rubber.

Thus, clay, snail shell powder, precipitated amorphous white silica, coal shale, and graphite have been investigated for possible utilization in the rubber industry with promising results [3] [4] [5] [6] [7]. Similarly, a number of bio-based fillers from natural resources have been investigated for possible use in the rubber industry. These include coconut fibre, velvet tamarind seed shell, and plantain peels [8] [9] [10].

Recently, the use of cereal straws to compound different types of rubber (ethylene propylene, methylvinylsilicone, butadiene-styrene and buta- 
diene-acrylonitrile) was reported [11]. The incorporation of the straws in the rubbers led to composites with increased cross-linking densities, and reduction in the curing times of the mixtures. Similarly, the straw vulcanizates exhibited significant increase in tear strength and hardness, high values of damping coefficients, and satisfactory strength properties. The effect of alkalized wheat straw treated with dipotassium phosphate on the thermal, mechanical and fire hazard properties of natural rubber was reported by Rybinski, Syrek, Maslowski, Miedzianowska, Strezelec, Zukowski and Brade [12]. It was found that the bio-fillers in the presence of added fire retardant increased the resistance of the composites to fire without significant adverse effect on the mechanical properties of the rubber composites. Ghani, Abd Karim, Ramli, Musa and Jaapar [13] formulated natural rubber latex films using rice husk ash and tacca starch as biofillers at 10 and $30 \mathrm{phr}$ filler contents. The optimum concentration of tacca starch filler was found to be $10 \mathrm{phr}$, and at optimum content, the tensile stress was $18 \mathrm{Mpa}$, while the elongation at break was $650 \%$. The tensile stress obtained at $300 \mathrm{~mm}$ elongation was $2 \mathrm{Mpa}$, while the tensile strength was $15 \mathrm{~N} / \mathrm{mm}$.

These natural fibre composites have potentials for many engineering applications. Though, natural fibres are light and easily accessible, they however, pose technological problems since they exhibit low compatibility with rubber matrix, and are hydrophilic. These problems are mainly minimized by the use of coupling agents to increase the adhesion between the fibre and rubber matrix or applying chemicals to modify the surfaces of fillers thereby minimizing water absorption and improving the mechanical properties of composites [14]

Although, the use of bio-based fillers in the rubber industry is not as popular as the use of mineral or in organic fillers, these bio-based fillers have several advantages when compared to the use of mineral or inorganic fillers in compounding natural rubber. These advantages include low density, ease of processing, non-abrasion to processing equipment, acceptable specific strength properties, environmental friendliness, biodegradable and low cost.

Pineapple leaf fibre (PLF) which is extracted from pineapple, a perennial herbaceous plant is one of the natural fibres that have high cellulose content of up to $80 \%$ and the highest tensile strength when compared to other natural fibres. Pineapple is widely grown in many regions of the world and varieties of the plant are available and used in various applications such as medicine and food. PLF is extracted from pineapple leaves by mechanical and retting methods, and fresh leaves of pineapple yield about $2 \%$ to $3 \%$ of the fibre. Being an important natural fibre that has high specific strength and rigidity, it is considered for use as an alternative raw material (filler) in reinforcing polymer composites. There are reports of reinforcing thermoset, thermoplastic, biodegradable plastics, and natural rubber with pineapple leaf fibre [15] [16] [17] [18].

The present paper which is an extension of a previous report [19] presents results obtained on the end-use properties of pineapple leaf fibre filled natural rubber. The pineapple leaf fibre (PLF) sieved to 75, 150 and $300 \mu \mathrm{m}$ particle sizes was used within filler contents, 0 to $40 \mathrm{phr}$. The properties of the rubber vulca- 
nizates investigated were abrasion resistance, hardness, swelling index and specific gravity. In an earlier communication [19], PLF was used to compound natural rubber and the study showed that pineapple leaf fibre enhanced the tensile, flexural, compression strengths and tensile modulus of the natural rubber vulcanizates whereas the elongation at break of the unfilled natural rubber vulcanizate was greater than those of filled rubber vulcanizates. In Nigeria, pineapple leaves presently have no identifiable industrial applications and can be seen littering farm yards as wastes. From the literature, few works have been carried out on compounding natural rubber with pineapple leaf fibre [17] [20]. Our present investigations on compounding natural rubber with pineapple leaf fibre are aimed at putting the usefulness of pineapple leaf fibre as a suitable filler for natural rubber on firm scientific basis. Utilization of PLF in the rubber industry will assure a new material (filler) that is naturally available, easy to process, ecofriendly, biodegradable, low cost, and a source of economic benefit to rural famers.

\section{Materials and Methods}

The following materials were used in this study.

1) Natural rubber crumbs which were obtained from Integrated Rubber Products PLC, Benin, Nigeria.

2) Carbon black (N330) was obtained from Campal Scientific and Technology Co., Onitsha, Nigeria.

3) Zinc oxide, 3,2,4-trimethyl-1,2-dihydroquinoline activator (TMQ), Mercaptobenzothiazolesulphanamide accelerator (MTBS), sulphur and stearic acid were supplied by Dunlop PLC, Lagos, Nigeria.

4) Processing oil was purchased from a chemical store at Onitsha, Nigeria.

5) Pineapple leaf fibre used as filler in this study was prepared from pineapple leaves collected locally at Umuagwo, Nigeria.

The pineapple leaf fibre was sieved to three particle sizes, 75, 150 and $300 \mu \mathrm{m}$ and characterized for oil absorption (ASTM D 1510, 1983), moisture content (ASTM D1509-13), pH (ASTM D 1512-05), specific gravity and iodine adsorption according to standard methods and the results have been reported [19].

The compounding and curing of the natural rubber vulcanizates were as described previously [19]. The abrasion resistance (ISO 4649 DIN) and hardness (ASTM D 2240) of the rubber vulcanizates were determined by standard methods. The specific gravity and swelling index of the vulcanizates were determined as described below.

The specific gravity of the rubber vulcanizates was determined by suspending vulcanizate specimens in air, and water using a thread during measurements and noting the weights. A beaker served as an immersion vessel. The specific gravity was calculated as,

$$
\text { Specific gravity }=a / b
$$

where $a$ is the mass of the specimen in air (g) and $b$ is the mass of specimen in water $(\mathrm{g})$ 
The swelling index of the rubber vulcanizates was determined using test samples of dimensions $25 \times 25 \mathrm{~mm}$. Each of the test specimen was first weighed and put into a sample bottle with a cover $25 \mathrm{~cm}^{3}$ of toluene was poured into the sample bottle and the bottle was subsequently equilibrated for $24 \mathrm{hr}$ at room temperature $\left(32^{\circ} \mathrm{C}\right)$. At the expiration of the required time, the sample was removed from the bottle using a pair of forcept. The solvent adhering on the surface of the sample was removed by carefully pressing the sample between filter paper wraps. Care was taken to ensure that the solvent absorbed by the sample was not removed during the process of wiping using the filter paper. The wet sample was weighed. All the weighings was done using an analytical weighing balance. The swelling index was calculated as,

$$
\text { Swelling Index }(\%)=W_{2}-W_{1} / W_{1} \times 100
$$

where:

$W_{1}=$ the initial dry weight of the sample $(\mathrm{g})$

$W_{2}=$ the weight of the sample after $24 \mathrm{hr}$ of immersion in toluene $(\mathrm{g})$

\section{End-Use Properties of Natural Rubber Vulcanizates}

\subsection{Abrasion Resistance}

Figure 1 shows the effect of filler content and particle size on the abrasion resistance of filled natural rubber. The incorporation of pineapple leaf fibre (PLF) into the rubber matrix was generally observed to increase the abrasion resistance of filled natural rubber vulcanizates. For PLF (particle size, $75 \mu \mathrm{m}$ ) filled natural rubber vulcanizates, no definite order on the variation of vulcanizates abrasion resistance with filler content could be observed. This may indicate that filler content is not a function of abrasion resistance and therefore, may be attributed to the degree of dispersion of the fillers in the rubber matrix.

However, for PLF (particle sizes, 150 and $300 \mu \mathrm{m}$ ) filled natural rubber vulcanizates, the abrasion resistance was found to decrease with increasing filler content up to $20 \mathrm{phr}$ filler incorporation, and thereafter, increased with increasing filler content. The abrasion resistance of PLF (particle size, $75 \mu \mathrm{m}$ ) filled natural rubber vulcanizates was found to increase with increases in filler content within 5 - $10 \mathrm{phr}$ filler incorporation, after which a decrease and increases in abrasion resistance was observed with increasing filler content. Carbon black exhibited better abrasion resistance in the rubber vulcanizates than the PLF filler studied at filler contents, 20, 30 and $40 \mathrm{phr}$. However, at the other filler contents investigated, the abrasion resistance of carbon black filled rubber vulcanizates generally was less than those of PLF filled rubber vulcanizates. The abrasion resistance of PLF filled natural rubber vulcanizate at filler content, $5 \mathrm{phr}$ was found to increase with increase in filler particle size whereas at filler content, $10 \mathrm{phr}$, the abrasion resistance decreased with increasing filler particle size.

\subsection{Hardness Test (Shore A)}

Figure 2 shows that the hardness of PLF (particle size, $75 \mu \mathrm{m}$ ) filled natural 
rubber decreased with increases in filler content, up to $20 \mathrm{phr}$ filler content, and thereafter, exhibited an increase and decrease at 30, and $40 \mathrm{phr}$ filler contents respectively. However, the PLF (particle sizes, 150 and $300 \mu \mathrm{m}$ ) filled natural rubber exhibited increases in vulcanizates hardness with increases in filler content, up to $10 \mathrm{phr}$ filler content and thereafter, exhibited irregular patterns on the increase of vulcanizate hardness with filler content.

The PLF filled natural rubber vulcanizates exhibited increases in vulcanizate hardness with increases in filler particle size at filler contents, 10 and $20 \mathrm{phr}$. The reverse behaviour was however, obtained at filler content, 5 phr where the hardness decreased with increases in filler particle size. The increases in vulcanizate hardness noted above at filler contents, 10 and 20 phr with increases in filler particle size is unexpected since a reduction in filler particle size provides greater surface area, and hence, better reinforcement [21].

The hardness of CB filled natural rubber vulcanizates generally increased with the increase in $\mathrm{CB}$ content except for the decrease obtained at filler content, 10 phr. Kruger, Hory and Wardle [22] who studied fly ash filled rubber reported increases in rubber hardness with increasing fly ash content. This result is expected because as more filler particles are incorporated into rubber, the elasticity of the rubber chain in reduced, thereby making the vulcanizate to be more rigid.

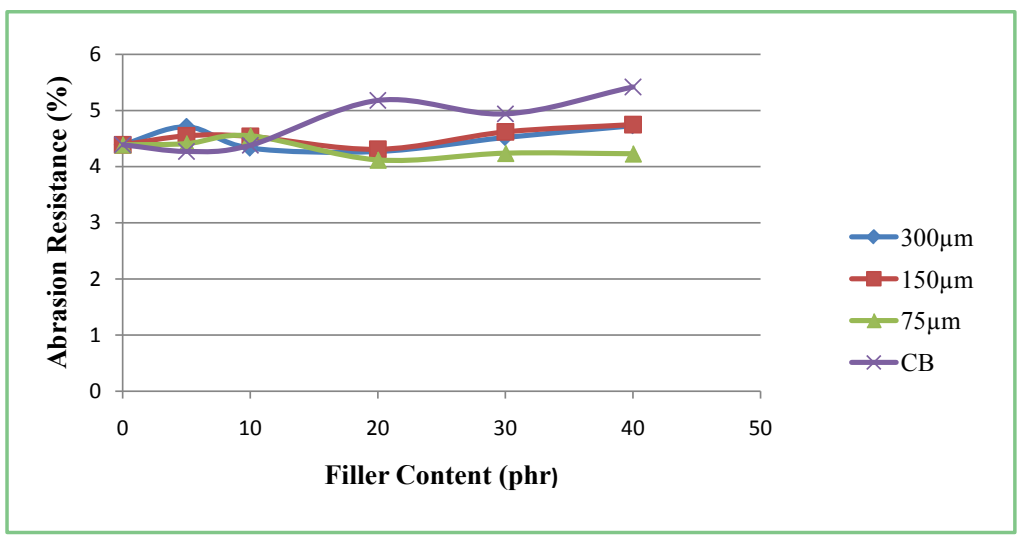

Figure 1. The effects of filler content and particle size on abrasion resistance of filled natural rubber.

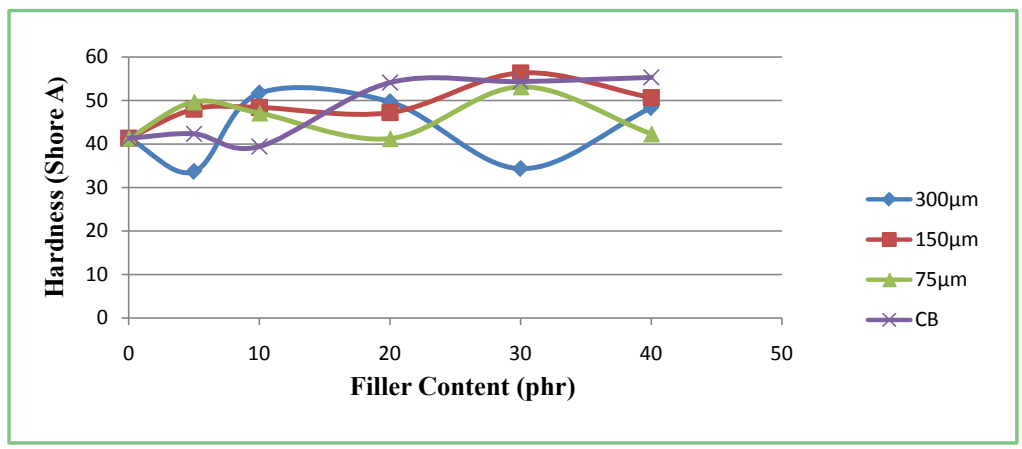

Figure 2. The effects of filler content and particle size on hardness of filled natural rubber. 
The hardness of filled natural rubber vulcanizates was generally greater than that for the unfilled rubber vulcanizate. However, the hardness of PLF (particle size, $300 \mu \mathrm{m}$ ) filled natural rubber vulcanizates at filler contents, 5 and $30 \mathrm{phr}$ were less than that for unfilled natural rubber vulcanizates.

CB exhibited higher vulcanizates hardness at filler contents, 20 and $40 \mathrm{phr}$ than PLF filled vulcanizates at the same filler contents: This can be attributed to the likely more uniform dispersion of $\mathrm{CB}$ in the rubber matrix resulting in better CB rubber interactions. Similarly, carbon black has a very high surface activity which provided greater reinforcement in rubber in comparison with PLF [9]. Thus, surface activity and better filler interactions are important factors that control the hardness of vulcanizates. Ahmed, Mohd and Abdulla [23] had reported that natural rubber forms a strong adsorptive bond with carbon black.

\subsection{Specific Gravity of Natural Rubber Vulcanizates}

Figure 3 shows the effects of filler content and particle size on the specific gravity of filled rubber vulcanizates. The figure shows that after the incorporation of $5 \mathrm{phr}$ of the fillers into natural rubber, the specific gravity of the vulcanizates increased with filler content and filler particle size. The specific gravity of PLF (75 and $150 \mu \mathrm{m}$ ) filled natural rubber vulcanizates generally decreased on incorporation of $5 \mathrm{phr}$ of the fillers into natural rubber while the specific gravity of PLF $(300 \mu \mathrm{m})$ and CB filled natural rubber remained unaffected.

The specific gravity of unfilled rubber vulcanizate is 0.99 . The PLF $(300 \mu \mathrm{m})$ filled natural rubber vulcanizates generally exhibited higher specific gravity in the vulcanizates at the filler contents studied and was highest at filler content, 5 phr. The specific gravity of PLF $(75 \mu \mathrm{m})$ filled natural rubber vulcanizates was generally the least at any filler content studied while those of CB and PLF (300 $\mu \mathrm{m}$ ) filled natural rubber vulcanizates were the same at filler contents 5, 10 and $20 \mathrm{phr}$.

Since materials are bought in terms of weight, and pieces or articles are in general sold by number, it follows that more pieces can be made with PLF of particle size $300 \mu \mathrm{m}$ as compared to the same weight of CB and the other particle sizes of PLF used. This could result to significant cost savings in the high-volume and low-cost commodity rubber market.

\subsection{Swelling Index of Natural Rubber Vulcanizates}

The swelling indices of the different filled rubber vulcanizates in toluene at room temperature are shown in Figure 4. Unfilled natural rubber vulcanizate has a swelling index of $2.71 \%$.

Figure 4 shows that the swelling index of PLF $(150 \mu \mathrm{m})$ filled natural rubber vulcanizates decreased with increases in filler content, up to $30 \mathrm{phr}$ filler incorporation, and later, increased at $40 \mathrm{phr}$ filler content. While the swelling indices of PLF $(75 \mu \mathrm{m})$ filled vulcanizates increased within filler contents, 5 to $10 \mathrm{phr}$ filler incorporation, that of PLF $(300 \mu \mathrm{m})$ filled vulcanizates decreased within the 


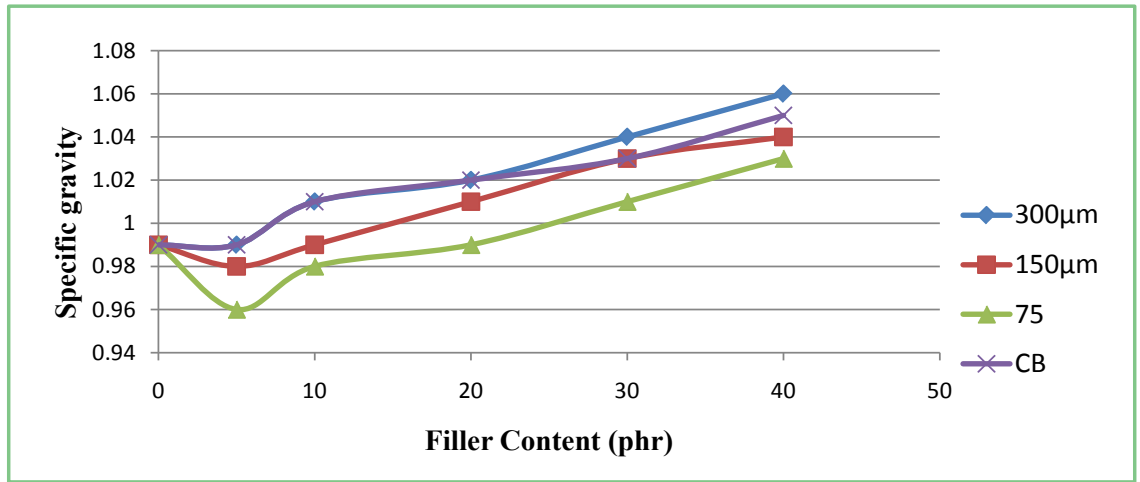

Figure 3. The effects of filler content and particle size on specific gravity of filled natural rubber.

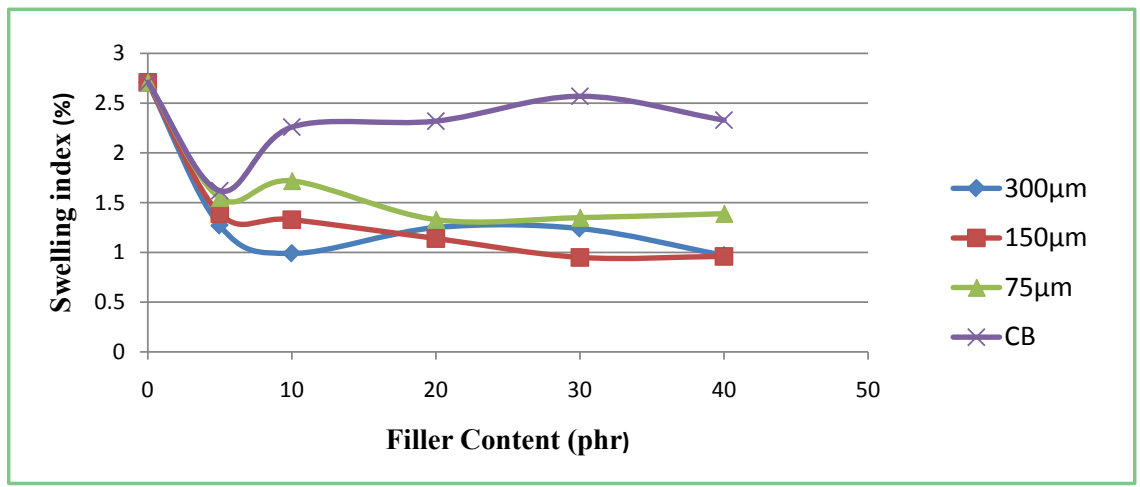

Figure 4. The effects of filler content and particle size on swelling index of filled natural rubber.

same filler content range considered after which irregular variation of swelling index with filler content was observed. The swelling indices of PLF (75 and 300 $\mu \mathrm{m})$ filled rubber vulcanizates did not show any definite order of variation with increases in filler content.

The observed decreases in swelling index with increases in filler content may arise as each filler particle behaves like an obstacle to the diffusing solvent molecule. As filler content increased in the rubber matrix, more and more obstacles were created to the diffusing molecules resulting in reduction in the amount of solvent absorbed [8].

The swelling indices of filled natural rubber vulcanizates were observed to decrease with increases in filler particle size at filler contents, 5 and 10 phr. The observed reduction in swelling index with increases in filler particle size is unexpected since decreases in filler particle size would lead to greater crossing linking of rubber, thereby, bringing the rubber chains closer, and intact. In the process, less solvent would be absorbed. The swelling indices of filled rubber vulcanizates at filler contents, 20 to $40 \mathrm{phr}$ were observed to decrease with increases in filler particle size, up to $150 \mu \mathrm{m}$ filler particle size, and thereafter, increased for filler of particle size, $300 \mu \mathrm{m}$.

The swelling indices of carbon black filled rubber vulcanizates were generally 
found to increase with increase in filler content, except for a decreased observed at high filler content, $40 \mathrm{phr}$. Carbon black filled natural rubber vulcanizates absorbed the highest amount of toluene (2.5\%) when compared to PLF filled rubber vulcanizates within the filler contents investigated.

Okoh, Osabohien and Egboh [24] in their study reported that Velvet tamarind seed shell filled natural rubber absorbed more solvent than CB filled vulcanizates.

\section{Conclusions}

The end-use properties of natural rubber vulcanizates determined were influenced by the filler contents and particle sizes. The natural rubber vulcanizates generally exhibited higher abrasion resistance than the unfilled. At 5 phr filler content, the abrasion resistance of the vulcanizates decreased with increasing filler content whereas at $5 \mathrm{phr}$ filler content, the abrasion resistance decreased with filler particle size.

The filled natural rubber vulcanizates generally had higher hardness than the unfilled except for natural rubber vulcanizates of PLF $(300 \mu \mathrm{m})$ which exhibited lower hardness at filler contents, 5 and $30 \mathrm{phr}$. The specific gravity of PLF (300 $\mu \mathrm{m}$ ) filled natural rubber vulcanizates was generally greater than the unfilled and the other filled vulcanizates and attained a maximum value (1.06) at filler content, $40 \mathrm{phr}$. The specific gravity of filled natural rubber vulcanizates was found to increase within filler contents, 10 to $40 \mathrm{phr}$.

The swelling indices of filled natural rubber vulcanizates in toluene were generally less than the unfilled at any filler content and particle size considered. The swelling indices were observed to decrease with increases in filler particle sizes at filler contents, 5 and $10 \mathrm{phr}$.

PLF $(150$ and $300 \mu \mathrm{m})$ were generally better than PLF $(75 \mu \mathrm{m})$ in improving the properties of natural rubber vulcanizates mostly observed at filler contents greater than $30 \mathrm{phr}$.

Pineapple leaf fibre is of low cost, easily available, non-abrasive to processing equipment and environmentally friendly. Considering the many rubber property improvements obtainable with its usage in natural rubber compounding, it is recommended that pineapple leaf fibre should find utilization in the rubber industry.

\section{Acknowledgements}

The authors express immense appreciation to the Department of Polymer Science and Engineering, Ahmadu Bello University, Zaria, Nigeria, the Department of Polymer Technology, Nigerian Institute of Leather and Science Technology, Zaria, Nigeria, the Centre for Energy and Research Office of Obafemi Awolowo University, Ile Efe, Nigeria, the Department of Polymer Technology, Auchi Polytechnic, Auchi, Nigeria, and Rubber Research Institute of Nigeria, Benin City for the opportunity to make use of their research facilities. 


\section{Conflicts of Interest}

The authors declare no conflicts of interest regarding the publication of this paper.

\section{References}

[1] Rubber Chemistry (2007) Matador Rubber.

[2] Bhatnagar, M.S. (2004) A Textbook of Polymer Chemistry and Technology. Volume 2, S. Chand and Co. Ltd., New Delhi.

[3] Kim, M., Kim, V., Chowdhury, S.R. and Kim, G. (2006) Melt-Compounded Butadiene Rubber Nancomposites with Improved Mechanical Properties and Abraision Resistance. Journal of Applied Polymer Science, 102, 2062-2066. https://doi.org/10.1002/app.23738

[4] Igwe, I.O. and Ejim, A.A. (2011) Studies on Mechanical and End-Use Properties of Natural Rubber Filled with Snail Shell Powder. Journal of Materials Sciences and Application, 2, 801-809. https://doi.org/10.4236/msa.2011.27109

[5] Ansarifar, A., Shiah, S.F. and Bennett, M. (2005) Optimizing the Chemical Bonding between Silanised Silica Nanofiller and Natural Rubber and Assessing Its Effects on the Properties of the Rubber. International Journal of Adhesion and Adhesives, 26, 454-463. https://doi.org/10.1016/j.ijadhadh.2005.06.008

[6] Zhao, M. and Xiang, Y. (2004) Natural Rubber Vulcanizate Reinforced by Modified Coalshale-Based Fillers. Journal of Applied Polymer Science, 93, 1397-1400. https://doi.org/10.1002/app.20506

[7] Yang, J., Tian, M., Jia, Q., Zhang, L. and Li, X. (2006) Influence of Graphite Particle Size and Shape on the Properties of NBR. Journal of Applied Polymer Science, 102, 4007-4015. https://doi.org/10.1002/app.24844

[8] Egwaikhide, P.A., Akporhonor, E.E. and Okieiemen, F.E. (2007) Effect of Coconut Fibre Filler on the Cure Characteristics, Physico-Mechanical and Swelling Properties of Natural Rubber Vulcanizates. International Journal of Physical Sciences, 2, 39-46.

[9] Osabohien, E. and Egboh, S.H.O. (2007) Cure Characteristics and Physico-Mechanical Properties of Natural Rubber Filled with the Seed Shells of Cherry (Chrysophyllum albidum). Journal of Applied Science and Environment Management, 11, 43-48.

[10] Sogbaike, O.E., Okieimen, E.F. and Edojariogba, P.O. (2005) Effect of Substitution of N330 Carbon Black with Carbonized Plantain Peels on Cure Characteristics, Physic-Mechanical and Swelling Properties of Natural Rubber Vulcanizates. Chemistry and Technology Journal, 1, 24-29.

[11] Maslowski, M., Miedzianowska, J. and Strzelec, K. (2019) The Potential Application of Cereal Straw as a Bio-Filler for Elastomer Composites. In: Polymer Bulletin, 1-18. https://doi.org/10.1007/s00289-019-02848-2

[12] Rybinski, P., Syrek, B., Maslowski, M., Miedzianowska, J., Strezelec, K., Zukowski, W. and Brado, D. (2018) Influence of Lignocellulose Fillers on Properties of Natural Rubber Composites. Journal of Polymers and the Environment, 26, 2489-2501. https://doi.org/10.1007/s10924-017-1144-9

[13] Ghani, H., Abd Karim, S.F., Ramli, R., Musa, M. and Jaapar, J. (2019) Effect of Bio-Fillers on Mechanical Properties of Natural Rubber Latex Films. Key Engineering Materials, 797, 249-254.

https://doi.org/10.4028/www.scientific.net/KEM.797.249 
[14] Samal, R.K. and Ray, M.C. (1997) Effect of Chemical Modifications on FTIR Spectra. 11 Physiochemical Behaviours of Pineapple Leaf Fibre (PALF). Journal of Applied Polymer Science, 64, 2119-2125.

https://doi.org/10.1002/(SICI)1097-4628(19970613)64:11<2119::AID-APP7>3.0.CO $\underline{; 2-\mathrm{M}}$

[15] Mishra, S., Misra, M., Tripathy, S.S., Nayak, S.K. and Mohanty, A.K. (2001) Potentiality of Pineapple Leaf Fibre as Reinforcement in PALF-Polyester Composite: Surface Modification and Mechanical Performance. Journal of Reinforced Plastics and Composites, 20, 321-334. https://doi.org/10.1177/073168401772678779

[16] George, J., Joseph, K., Bhagawan, S.S. and Thomas, S. (1993) Influence of Short Pineapple Fibre on the Viscoelastic Properties of Low Density Polyethylene. Materials Letters, 18, 163-170. https://doi.org/10.1016/0167-577X(93)90119-I

[17] Luo, S. and Netravali, A.N. (1999) Interfacial and Mechanical Properties of Environmentally-Friendly Green Composites from Pineapple Fibres and Poly(hydroxybutyrate-co-valerate) Resin. Journal of Materials Science, 34, 3709-3719.

[18] Bhattacharyya, J.C.T.B. and Biswas, A.K. (1986) Short Pineapple Leaf Fibre Reinforced Rubber Composites. Plastics and Rubber Processing and Applications, 6, 119-125.

[19] Ekwueme, C.C. and Igwe, I.O. (2018) Cure Characteristics and Mechanical Properties of Pineapple Leaf Fibre Filled Natural Rubber. Journal of Minerals and Materials Characterization and Engineering, 6, 601-617. https://doi.org/10.4236/jmmce.2018.66043

[20] Lopattananon, N., Panawarangkul, K., Sahakaro, K. and Ellis, B. (2007) Performance of Pineapple Leaf Fibre Natural Rubber Composites: The Effect of Fibre Surface Treatments. Journal of Applied Polymer Science, 102, 1974-1984. https://doi.org/10.1002/app.24584

[21] Zhang, L., Wang, Y., Way, V., Sin, Y. and Yu, D. (2000) Morphology and Mechanical Properties of Clay/Styrene-Butadiene Rubber Nanocomposites. Journal of Applied Polymer Science, 78, 1873-1878. https://doi.org/10.1002/1097-4628(20001209)78:11<1873::AID-APP40>3.0.CO;2-8

[22] Kruger, R.A., Hory, M. and Wardle, D. (1999) The Use of Fly Ash Fillers in Rubber. International Ash Utilization Symposium. Centre for Applied Energy Research University of Kentucky, 72.

[23] Ahmad, A., Mohd, D.H. and Abdullah, I. (2004) Mechanical Properties of Filled NR/LLDPE Blends. Iranian Polymer Journal, 13, 173-178.

[24] Okoh, B.E., Osabohien, E. and Egboh, S.H.O. (2014) The Reinforcing Potentials of Velvet tamarind Seed Shell as a Filler in Natural Rubber Compounds. International Journal of Biological and Chemical Sciences, 8, 2367-2376. 